\title{
Mechanochemical preparation of chrysomycin A self-micelle solid dispersion with improved solubility and enhanced oral bioavailability
}

\author{
Zhuomin Xu' ${ }^{1}$, Shanshan Zheng ${ }^{1}$, Xin Gao ${ }^{1}$, Yulu Hong ${ }^{1}$, Yue Cai ', Qiuqin Zhang ${ }^{1}$, Jiani Xiang ${ }^{1}$, Dehui Xie', \\ Fuxing Song ${ }^{2}$, Huawei Zhang ${ }^{1}$, Hong Wang ${ }^{1}$ and Xuanrong Sun ${ }^{1 *}$ (D)
}

\begin{abstract}
Background: Chrysomycin A (CA) has been reported as numerous excellent biological activities, such as antineoplastic and antibacterial. Though, poor solubility of CA limited its application in medical field. Due to good amphiphilicity and potential anticancer effect of disodium glycyrrhizin $\left(\mathrm{Na}_{2} \mathrm{GA}\right)$ as an excipient, an amorphous solid dispersion $\left(\mathrm{Na}_{2} \mathrm{GA} / \mathrm{CA}-\mathrm{BM}\right)$ consisting of $\mathrm{CA}$ and $\mathrm{Na}_{2} \mathrm{GA}$ was prepared in the present study by mechanochemical technology (roll mill ML-007, zirconium balls, 30 rpm, 2.5 h) to improve the solubility and oral bioavailability of CA. Then, $\mathrm{Na}_{2} \mathrm{GA} / \mathrm{CA}-\mathrm{BM}$ was self-assembled to micelles in water. The interaction of $\mathrm{CA}$ and $\mathrm{Na}_{2} \mathrm{GA}$ in solid state were investigated by $\mathrm{X}$-ray diffraction studies, polarized light microscopy, and scanning electron microscope. Meanwhile, the properties of the sample solution were analyzed by dynamic light scattering and transmission electron. Furthermore, the oral bioavailability and antitumor ability of $\mathrm{Na}_{2} \mathrm{GA} / \mathrm{CA}-\mathrm{BM}$ in vivo were tested, providing a theoretical basis for future application of CA on cancer therapy.
\end{abstract}

Results: $\mathrm{CA}$ encapsulated by $\mathrm{Na}_{2} \mathrm{GA}$ was self-assembled to nano-micelles in water. The average diameter of nanomicelle was $131.6 \mathrm{~nm}$, and zeta potential was $-11.7 \mathrm{mV}$. Three physicochemical detections showed that CA was transformed from crystal into amorphous form after treated with ball milling and the solubility increased by 50 times. Na2GA/CA-BM showed a significant increase of the bioavailability about two time that of free CA. Compared with free $\mathrm{CA}$, the in-vivo antitumor studies also exhibited that $\mathrm{Na}_{2} \mathrm{GA} / \mathrm{CA}-\mathrm{BM}$ had an excellent inhibition of tumor growth.

Conclusions: $\mathrm{Na}_{2} \mathrm{GA} / \mathrm{CA}-\mathrm{BM}$ nanoparticles $(131.6 \mathrm{~nm},-11.7 \mathrm{mV}$ ) prepared by simple and low-cost mechanochemical technology can improve oral bioavailability and antitumor efficacy of CA in vivo, suggesting a potential formulation for efficient anticancer treatment.

Keywords: Chrysomycin A, Mechanochemistry, Ball milling, Solid dispersion, Self-micelle, Bioavailability, Antitumor

\footnotetext{
*Correspondence: sunxr@zjut.edu.cn

${ }^{1}$ Collaborative Innovation Center of Yangtze River Delta Region Green

Pharmaceuticals and College of Pharmaceutical Science, Zhejiang University of Technology, Hangzhou 310014, China

Full list of author information is available at the end of the article
}

\begin{abstract}
Introduction
Chrysomycins is a novel antibiotic complex isolated from Streptomyces spp, containing compounds of C-glycosides antitumor actives [1]. Especially, Chrysomycin A (CA, Fig. 1) is the major analogue of chrysomycins and plays the most potent role in this complex [2]. Compared with the clinically used anticancer agent doxorubicin,
\end{abstract}

(c) The Author(s) 2021. This article is licensed under a Creative Commons Attribution 4.0 International License, which permits use, sharing, adaptation, distribution and reproduction in any medium or format, as long as you give appropriate credit to the original author(s) and the source, provide a link to the Creative Commons licence, and indicate if changes were made. The images or other third party material in this article are included in the article's Creative Commons licence, unless indicated otherwise in a credit line to the material. If material is not included in the article's Creative Commons licence and your intended use is not permitted by statutory regulation or exceeds the permitted use, you will need to obtain permission directly from the copyright holder. To view a copy of this licence, visit http://creativeco mmons.org/licenses/by/4.0/. The Creative Commons Public Domain Dedication waiver (http://creativecommons.org/publicdomain/ zero/1.0/) applies to the data made available in this article, unless otherwise stated in a credit line to the data. 


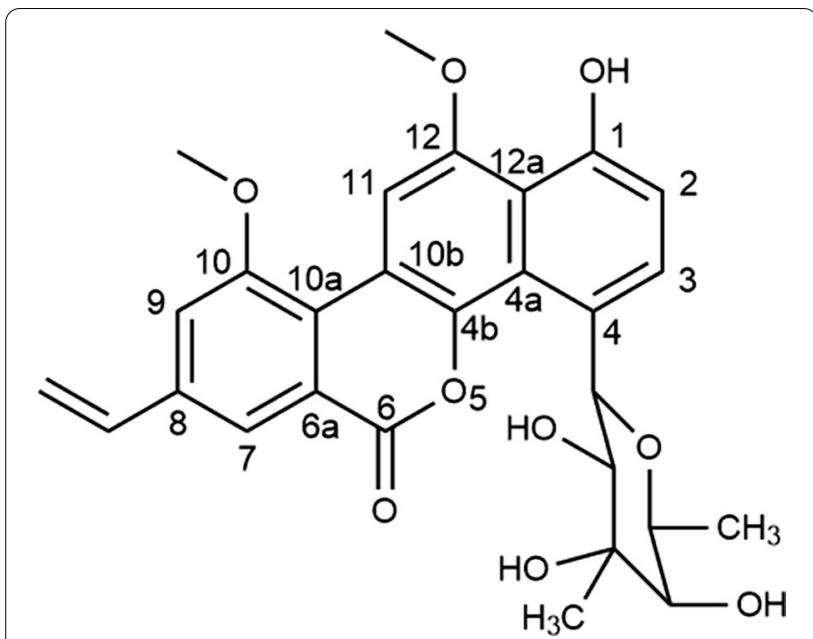

Fig. 1 Chemical structure of chrysomycin A

CA shows significant cytotoxicity toward cancer cells because of its vinyl group in the 8-position [3, 4]. In addition to strong antineoplastic and antibacterial properties of CA [5-7], it is thought to act as an inhibitor of the catalytic activity of human topoisomerase II [8]. Besides, CA equips with strong antifungal profile, and its cytotoxicity to normal cells can be negligible [2]. Meanwhile, it has no effect on the lysis of red blood cells [6]. All these characteristics indicate that CA has the potential to be a good anti-tumor, anti-bacterial and even anti-fungal candidate. Nonetheless, the oral bioavailability of CA is low owe to its poor solubility in water, which restricts its clinical application. To the best of our knowledge, there are no studies on how to overcome these shortcomings of CA.

Generally, several approaches were employed to improve drug insolubility and bioavailability, such as preparation of polymeric micelles $[9,10]$, cyclodextrins inclusion complex $[11,12]$, solid dispersions (SDs) [13, 14], self-emulsifying drug delivery system [15], and so on. In the methods mentioned above, most of them need multiple organic solvents (e.g., dimethyl sulfoxide, N,Ndimethylformamide, dichloromethane, etc.), large quantity of surfactants, complex procedures, long preparation time, or expensive excipients (including cholesterol, lipids) [16]. Those are considered unfriendly to the environment, and may increase the risk of solvent exposure during preparation and the cost of production.

Mechanochemical technology has become extensively popular in the field of pharmaceutical sciences for its important role in the development of green synthesis $[17,18]$, cocrystal synthesis $[19,20]$, and amorphous SDs $[21,22]$. When the high intensity of mechanical energy is transferred to the solid state substances, the strain is generated and may cause plastic deformation and concurrent changes in the crystal structure along with crystalline phase transitions and amorphization [23]. All the changes may potently enhance the solubility and bioavailability [24]. Compared with traditional "liquid phase" way, mechanochemical treatment provides significant advantages such as one-step technological process, absence of solvents, and low operating cost.

Disodium glycyrrhizinate $\left(\mathrm{Na}_{2} \mathrm{GA}\right)$ is the salt formation of glycyrrhizic acid (GA), which can undergo hydrolysis in aqueous solutions and generated free GA. As for GA, it is a good soluble natural saponin, having antiviral [25], anti-inflammatory [26] and anticancer [27] properties. Apart from those features, GA forms non-covalent compounds with various drugs due to its amphiphilicity. Such supramolecular compounds could increase the solubility of hydrophobic drugs up to dozens of times, and enhance the permeability of drug through cell membranes [2830]. In contrast, $\mathrm{Na}_{2} \mathrm{GA}$ solution has lower viscosity and more environment-friendly than GA solution. Meanwhile, $\mathrm{Na}_{2} \mathrm{GA}$ has also been reported to have antitumor activity. Zhang et al. [16] formed an amorphous SD of curcumin and $\mathrm{Na}_{2} \mathrm{GA}$ utilizing mechanochemistry to enhance the bioavailability and cytotoxic activity of curcumin. Zhu et al. [22] encapsulated SN-38 into $\mathrm{Na}_{2} \mathrm{GA}$ for preparing a $\mathrm{SN}-38$ self-micelle SD resulting in markly improving the solubility and antitumor activity of SN-38.

Given that mechanochemical technology and $\mathrm{Na}_{2} \mathrm{GA}$ have the potential to improve the solubility and bioavailability of water insoluble drug, in this study, solid dispersion of CA were prepared mechanical milling with $\mathrm{Na}_{2} \mathrm{GA}$. The physical characteristics, solubility, pharmacokinetics, tissue distribution and anti-tumor activity of $\mathrm{CA}$ as an amorphous SD were further investigated.

\section{Materials and methods Materials}

CA was obtained from professor Fuxing Song (Beijing Technology and Business University, purity >99\%). Disodium salt of glycyrrhizic acid $\left(\mathrm{Na}_{2} \mathrm{GA}\right)$ was purchased from Shanxi Pioneer Biotech Co. Ltd. (Xian, China, purity >98\%). Acetonitrile was obtained from Tedia Company, Inc. (Fairfield, OH, USA, HPLC grade). Formic acid with purity $>88 \%$ was purchased from Aladdin BioChem Technology Co., Ltd. (Shanghai, China). Roswell Park Memorial Institute 1640 (RPMI-1640) cell culture medium, fetal bovine serum (FBS) and penicillin/ streptomycin were all purchased from Gibco BRL (Gaithersburg, MD, USA).

\section{Cells and animals}

The mouse melanoma cell line B16-F10, the human breast cancer cell line MCF-7, the human hepatocellular carcinoma cell line $\mathrm{HepG}_{2}$ was purchased from the China 
Center for Type Culture Collection (Wuhan, China). The cells were cultured in RPMI-1640 (B16-F10 cells) or DMEM (MCF-7 cells and HepG2 cells) containing 10\% FBS and $1 \%$ antibiotics (penicillin/streptomycin).

Female ICR mice (5-6 weeks of age, 18-20 g body weight) and female C57BL/6 mice (5-6 weeks of age, 16-18 g) used in the experiments were provided by the Zhejiang Academy of medical Science, conducting with the approval of the animal experiment center of Zhejiang University of Technology. All the animals were performed in strict compliance with the PR China legislation for the use and care of laboratory animals.

\section{Fabrication of nanoparticles by mechanochemical treatment}

The roll mill ML-007 (Wiggens, German) was used to prepare samples. Briefly, $0.15 \mathrm{~g} \mathrm{CA}$ and $14.85 \mathrm{~g} \mathrm{Na}_{2} \mathrm{GA}$ (weight ratio $1 / 99$ ) were added to $300 \mathrm{~mL}$ vial with $660.0 \mathrm{~g}$ zirconium balls (diameter $22 \mathrm{~mm}$ ) with milling time of $3 \mathrm{~h}$, rotation speed $30 \mathrm{rpm}$ and samples were picked out at $0.5,1,1.5,2,2.5 \mathrm{~h}$, and $3 \mathrm{~h}$, respectively. In addition, a mixture of $\mathrm{Na}_{2} \mathrm{GA}$ and $\mathrm{CA}$ (weight ratio was same as above) by ordinary physical treating without ball milling, were prepared for comparing with the ball milling products. At last, the ball-milling products with different milling time were described as BM-0.5 h, BM-1.0 h, BM-1.5 h, BM-2.0 h, BM-2.5 h, BM-3 h, and the physical milling product was described as $\mathrm{Na}_{2} \mathrm{GA} /$ CA-PM.

\section{Analysis of chrysomycin A by HPLC}

The appropriate amounts of samples were dissolved completely in a mixture solution (deionized water to acetonitrile, $1: 1, \mathrm{v} / \mathrm{v}$ ) respectively, and filtered through a $0.22 \mu \mathrm{m}$ filter paper. Then, the filterate was determined by a high performance liquid chromatography (HPLC, Aglient 1260 infinity II) equipped with column Inertisil O DS-3 $\mathrm{C}_{18}(250 \mathrm{~mm} \times 4.6 \mathrm{~mm}, 5 \mu \mathrm{m}$, GL Science Inc., Japan $)$ at $25{ }^{\circ} \mathrm{C}$, and a UV detector set at a wavelength of $254 \mathrm{~nm}$. Acetonitrile- $0.1 \%$ formate water $(40: 60)$ was used as eluent $(\mathrm{pH}=2.6-2.8)$ with the flow rate of $1.0 \mathrm{~mL} / \mathrm{min}$.

\section{Solubility determination}

To determine the solubility, an overdose of samples and $\mathrm{CA}$, were put into $500 \mu \mathrm{L}$ of deionized water respectively and stirred for $12 \mathrm{~h}$ at $25{ }^{\circ} \mathrm{C}$. Finally, these solutions were filtered and analyzed by HPLC.

\section{Powder X-ray diffraction (XRD)}

$\mathrm{X}$-ray diffraction test of samples was implemented with a Bruker $\mathrm{D}_{2}$ Phase diffractometer (Buker, Germany) by using $\mathrm{CuK} \alpha$ radiation. Step range: $3^{\circ}-40^{\circ}$. Counter speed: $3.7^{\circ} / \mathrm{min}$. All the data were analyzed through GraphPad Prism 7.

\section{Polarized light microscopy (PLM)}

To distinguish the refraction phenomenon of samples, a small amount of solid powder was placed on microscope slide and observed by an Olympus CX41 polarized microscope (Japan) with a CCD camera (HTC1600, China). All the pictures were obtained at $10 \times$ resolution.

\section{Scanning electron microscopy (SEM)}

After samples were coated with platinum by a Leica EM ACE200 Vacuum Coater (Germany), SEM (ZEISS Gemini500, Germany) was performed to acquire electronic images. The Coating parameter: amperage $30 \mathrm{~mA}$, spraying time $100 \mathrm{~s}$.

\section{Particle characterization, zeta potential and stability}

The physicochemical properties of samples containing hydrodynamic diameter, polydispersity index (PDI), and zeta potential, were detected using dynamic light scattering (DLS) instrument (Zetasizer NanoZS, Malvern Instruments, Malvern, UK) at $25^{\circ} \mathrm{C}$. Before being measured, all samples were dissolved in deionized water at the concentration of $1 \mathrm{mg} / \mathrm{mL}$, then filtered by a $0.22 \mu \mathrm{m}$ filter. The sample was dissolved in DMEM with $10 \%$ FBS. Then the change in particle size and PDI of micelles were measured for $72 \mathrm{~h}$.

\section{Determination of the critical micelle concentration}

$3 \mu \mathrm{g}$ of Nile red dissolved in $90 \mu \mathrm{L} \mathrm{CH}_{2} \mathrm{Cl}_{2}$ was added to a series pf vials, and $\mathrm{CH}_{2} \mathrm{Cl}_{2}$ was evaporated at room temperature. The aqueous solutions of ball milling sample with various concentrations ranging from 0.001 to $10 \mathrm{mg} / \mathrm{mL}$ were added into the vials, stirred for $12 \mathrm{~h}$. The fluorescence intensity of Nile red (excitation wavelength: $579 \mathrm{~nm}$, emission wavelength: $620 \mathrm{~nm}$ ) in these solutions was measured by a microplate reader (Flexstation 3 , Molecular Devices LLC, Sunnyvale, CA, USA).

\section{Transmission electron microscopy (TEM)}

To observe the morphology of micelle, samples were configured into $1 \mathrm{mg} / \mathrm{ml}$ solution. One drop of sample was dripped on a carbon Formvar-coated cooper grid for a minute, and then were dried below the infrared light. Finally, TEM (Hitachi HT700 EXALENS, Japan) was at a working voltage of $100 \mathrm{kV}$ to form the morphology of samples.

\section{In vitro cell viability studies}

Cell viability of free $\mathrm{CA}, \mathrm{Na}_{2} \mathrm{GA}$, and the ball milling sample on MCF-7, HepG ${ }_{2}$, and B16-F10 cells was evaluated by MTT assay. The cells were incubated in 96-well 
plates at a density of $4 \times 10^{3}$ cells per well. After $12 \mathrm{~h}$ of incubation at $37{ }^{\circ} \mathrm{C}$ with $5 \% \mathrm{CO}_{2}$, the medium was replaced by $100 \mu \mathrm{L}$ fresh medium containing the suspension of free $\mathrm{CA}, \mathrm{Na}_{2} \mathrm{GA}$, or the ball milling sample with a series of concentration. After another $48 \mathrm{~h}$ of incubation, the medium was removed and the fresh medium containing $10 \mu \mathrm{L}$ of MTT $(5 \mathrm{mg} / \mathrm{mL})$ were added to each well. The cells were further incubated for $4 \mathrm{~h}$, then the medium was removed, and $100 \mu \mathrm{L}$ DMSO was added to dissolve the formazan crystals. The absorbance of each wells was measured be a microplate reader at the wavelength of $570 \mathrm{~nm}$. Cell viability in each group was expressed as a percentage relative to that of the untreated control.

\section{Cellular uptake studies}

For qualitative analysis and intracellular localization, coumarin-6-loaded ball milling products (NPs/C6) were prepared. $1 \mathrm{mg}$ coumarin-6, were mixed with $1 \mathrm{mg} \mathrm{Na} \mathrm{Na}_{2} \mathrm{GA}$ CA-BM powders and then dissolved in $200 \mu \mathrm{L}$ tetrahydrofuran completely. Then about $1 \mathrm{~mL}$ distilled water was added dropwise with continuously stirring for extra $12 \mathrm{~h}$. When tetrahydrofuran was evaporated, the labeled NPs were stored at $-20{ }^{\circ} \mathrm{C}$.

B16-F10 cells were seeded in a 24-well plate as a density of $2 \times 10^{4}$ cells per well, and incubated for $12 \mathrm{~h}$ before use. Then the cells were incubated with $10 \mu \mathrm{g} /$ $\mathrm{mL} \mathrm{NPs/C6.} \mathrm{Four} \mathrm{hours} \mathrm{later,} \mathrm{the} \mathrm{cells} \mathrm{were} \mathrm{washed}$ three times with $4{ }^{\circ} \mathrm{C} \mathrm{PBS}$, fixed with $4 \%$ paraformaldehyde for $15 \mathrm{~min}$ at room temperature, and stained with Hoechst 33342 for another $10 \mathrm{~min}$. Finally, the plate was observed under a fluorescence microscope (Olympus IX73, Japan) after washed with $4{ }^{\circ} \mathrm{C}$ PBS three times.

\section{Pharmacokinetic evaluation}

Ten female ICR mice were randomly divided into two groups $(\mathrm{CA}$ and the ball-milling produc to evaluate the pharmacokinetic of samples. The samples were dispersed in deionized water and were intragastriclly administered to the mice at the equivalent dose of $50 \mathrm{mg} / \mathrm{kg} \mathrm{CA}$. Next, $0.2 \mathrm{~mL}$ of blood was collected into prepared heparinized tubes at different time points $(0.25,0.5,1,2,4,8$, 12 , and $24 \mathrm{~h}$ ) after administration, and then centrifuged at $5000 \mathrm{rpm}, 4{ }^{\circ} \mathrm{C}$ for $5 \mathrm{~min}$ to obtain plasma supernatant. After taking plasma to a cleaning tube, a certain volume of acetonitrile was added to the supernatant (the volume ratio was $3: 1$ ). When protein precipitates generated, the mixture was vortexed for $2 \mathrm{~min}$, and centrifugated at $10,000 \mathrm{rpm}, 4{ }^{\circ} \mathrm{C}$ for $10 \mathrm{~min}$. Then, supernatant from the mixture was extracted and stored at $-80^{\circ} \mathrm{C}$ for $2 \mathrm{~h}$ for furth use. After being thawed, samples were centrifugated $\left(10,000 \mathrm{rpm}, 4^{\circ} \mathrm{C}\right)$ for $10 \mathrm{~min}$ and take out. At last, the sample was filtered by a $0.22 \mu \mathrm{m}$ filter for HPLC analysis.

\section{In vivo tissue biodistribution study}

To investigate the tissue biodistribution of $\mathrm{CA}$ and the ball-milling product, ten female ICR mice were stochastically divided into two groups. The ball-milling sample and CA were formulated as suspensions at a concentration of $5 \mathrm{mg} / \mathrm{mL}$. The dose for each intragastric administration was $50 \mathrm{mg} / \mathrm{kg}$ equivalent to the concentration of $\mathrm{CA}$. At the set time points $(2 \mathrm{~h}, 6 \mathrm{~h}, 12 \mathrm{~h})$, major organs containing heart, liver, spleen, lung, kidney, brain, skeletal muscle were resected and wash with $10 \mathrm{mM}$ phosphate buffered saline (PBS). After being dried and weighted, the organs were divided into small pieces and homogenized with deionized water at ratio of $1: 2(\mathrm{~g} / \mathrm{mL})$. To extract CA from tissues, the homogenate was added with acetonitrile (the ratio was 1:3). Then the mixture was vortexed for $1 \mathrm{~min}$ and centrifuged at $10,000 \mathrm{rpm}, 4{ }^{\circ} \mathrm{C}$ for $10 \mathrm{~min}$. Ultimately, supernatant was removed from the mixture to a clean tube and stored at $-80^{\circ} \mathrm{C}$ for HPLC analysis.

\section{In vivo antitumor efficacy}

The tumor-bearing model was established by subcutaneously injecting $1 \times 10^{6}$ B16-F10 cells in $100 \mu \mathrm{L}$ of PBS into female C57BL/6 mice at the right flank. When the tumor volume reached to about $35-60 \mathrm{~mm}^{3}$, the mice were casually divided into three groups ( $n=6 /$ group). Each mouse was intragastrically administered with an equivalent dose of $50 \mathrm{mg} / \mathrm{kg} \mathrm{CA}\left(\mathrm{Na}_{2} \mathrm{GA} / \mathrm{CA}-\mathrm{BM}\right.$ and CA suspension) every 2-3 days, whereas the control group was given PBS. The volume of administration was $200 \mu \mathrm{L}$ per mouse.

The first day of administration was recorded as day 0 , the tumor growth and body weight change were monitored every $2-3$ days. The tumor volume was measured with a caliper and was calculated as follows: tumor volume $=0.5 \times$ length $\times$ width $^{2}$. On the 12th day, the mice were sacrificed, then the tumor and major organs (hearts, lungs, livers, kidneys and spleens) were washed with PBS and weighed. Moreover, tumor paraffin sections of three groups were stained with $\mathrm{H} \& \mathrm{E}$ staining to observe pathological changes.

\section{Statistical analysis}

Data were reported as mean \pm standard error of the mean, using the unpaired Student's $t$-test. Values of $* p<0.05$ and $* * * 0<0.001$ calculated by GraphPad Prism 7 were considered significant and extremely significant, respectively.

\section{Results and discussion}

Solubility determination of chrysomycin A SDs

The aqueous solubility of $\mathrm{CA}$ and its ball milling products was shown in Table 1 . It could be seen that there 
Table 1 The solubility of pure CA and its mechanical processed products

\begin{tabular}{llcc}
\hline Sample & $\begin{array}{l}\text { Ball-milling } \\
\text { time }(\mathbf{h})\end{array}$ & Solubility $(\boldsymbol{\mu g} / \mathbf{m L})$ & $\begin{array}{l}\text { Increase } \\
\text { solubility } \\
\text { (times) }\end{array}$ \\
\hline CA & - & $1.68 \pm 0.66$ & - \\
BM-0.5 h & 0.5 & $38.39 \pm 8.86$ & $\sim 23$ \\
BM-1.0 h & 1 & $50.97 \pm 27.89$ & $\sim 30$ \\
BM-1.5 h & 1.5 & $56.21 \pm 16.89$ & $\sim 33$ \\
BM-2.0 h & 2 & $63.78 \pm 11.53$ & $\sim 38$ \\
BM-2.5 h & 2.5 & $82.40 \pm 25.32$ & $\sim 50$ \\
BM-3.0 h & 3 & $65.23 \pm 17.16$ & $\sim 39$ \\
\hline
\end{tabular}

were significant differences between CA $(1.68 \pm 0.66 \mu \mathrm{g} /$ $\mathrm{mL}$ ) and the SD samples. In addition, the solubility of CA SDs was gradually increased by prolonging the ball milling time from 0.5 to $2.5 \mathrm{~h}$. The drug milled for long time provided better wettability and dispersibility which was formed as the amorphous complex and encapsulated in a hydrophilic carrier. The solubility of $\mathrm{Na}_{2} \mathrm{GA} /$ CA SD was excellently raised after the formation. However, an unwanting decreased of the solubility could be observed after milling for $3 \mathrm{~h}$. It was supposed that further aggregation of the particles resulted in their higher surface energy with increased time of milling process, and thereby decreasing the solubility [31]. Since the sample created by ball milling for $2.5 \mathrm{~h}$ had the best solubility $(82.41 \pm 25.32 \mu \mathrm{g} / \mathrm{mL})$ which was increased about 50 times compared with unprocessed pure $\mathrm{CA}$, it was chose as chrysomycin A SDs candidate to study the subsequent experiments and was described as $\mathrm{Na}_{2} \mathrm{GA} / \mathrm{CA}-\mathrm{BM}$.

\section{Physicochemical changes of chrysomycin A SDs}

Physicochemical changes were analyzed by XRD, PLM and SEM. The X-ray diffractograms of $\mathrm{CA}, \mathrm{Na}_{2} \mathrm{GA}$, $\mathrm{Na}_{2} \mathrm{GA} / \mathrm{CA}-\mathrm{Pand} \mathrm{Na}_{2} \mathrm{GA} / \mathrm{CA}-\mathrm{BM}$ were shown in Fig. 2a. $\mathrm{CA}$ displayed several sharp peaks at diffraction angles (20) of $6.67,7.50,9.47,15.09,21.60$, indicating its crystalline form. On the other hand, the characteristic peaks of CA existed in the mechanical treated sample indicating it was still a crystal form. However, the crystallization peaks of $\mathrm{CA}$ were markedly decreased in the diffraction spectrum of $\mathrm{Na}_{2} \mathrm{GA} / \mathrm{CA}-\mathrm{PM}$, and even no characteristic peaks were observed in the sample of $\mathrm{Na}_{2} \mathrm{GA} / \mathrm{CA}-\mathrm{BM}$. The phenomenon could be attributed to the completely loss of crystalline of CA owing to high-intensity ball milling process. These XRD results further confirmed that $\mathrm{CA}$ which was dispersed in excipient $\mathrm{Na}_{2} \mathrm{GA}$ to form an amorphous complex by ball milling.

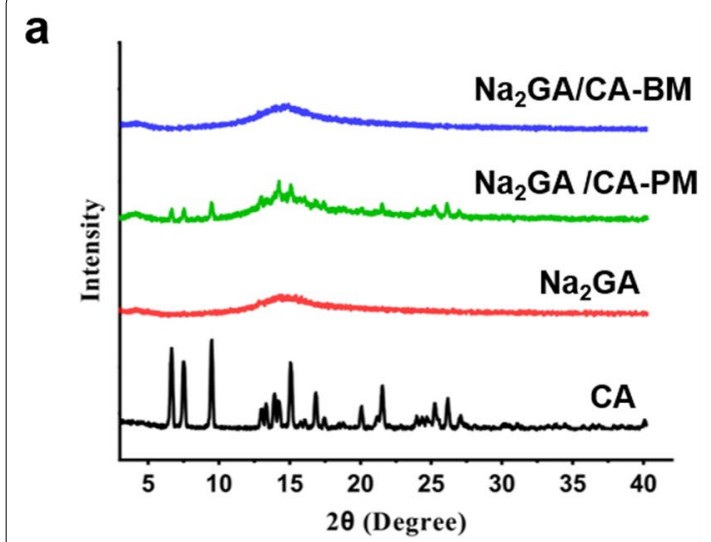

b
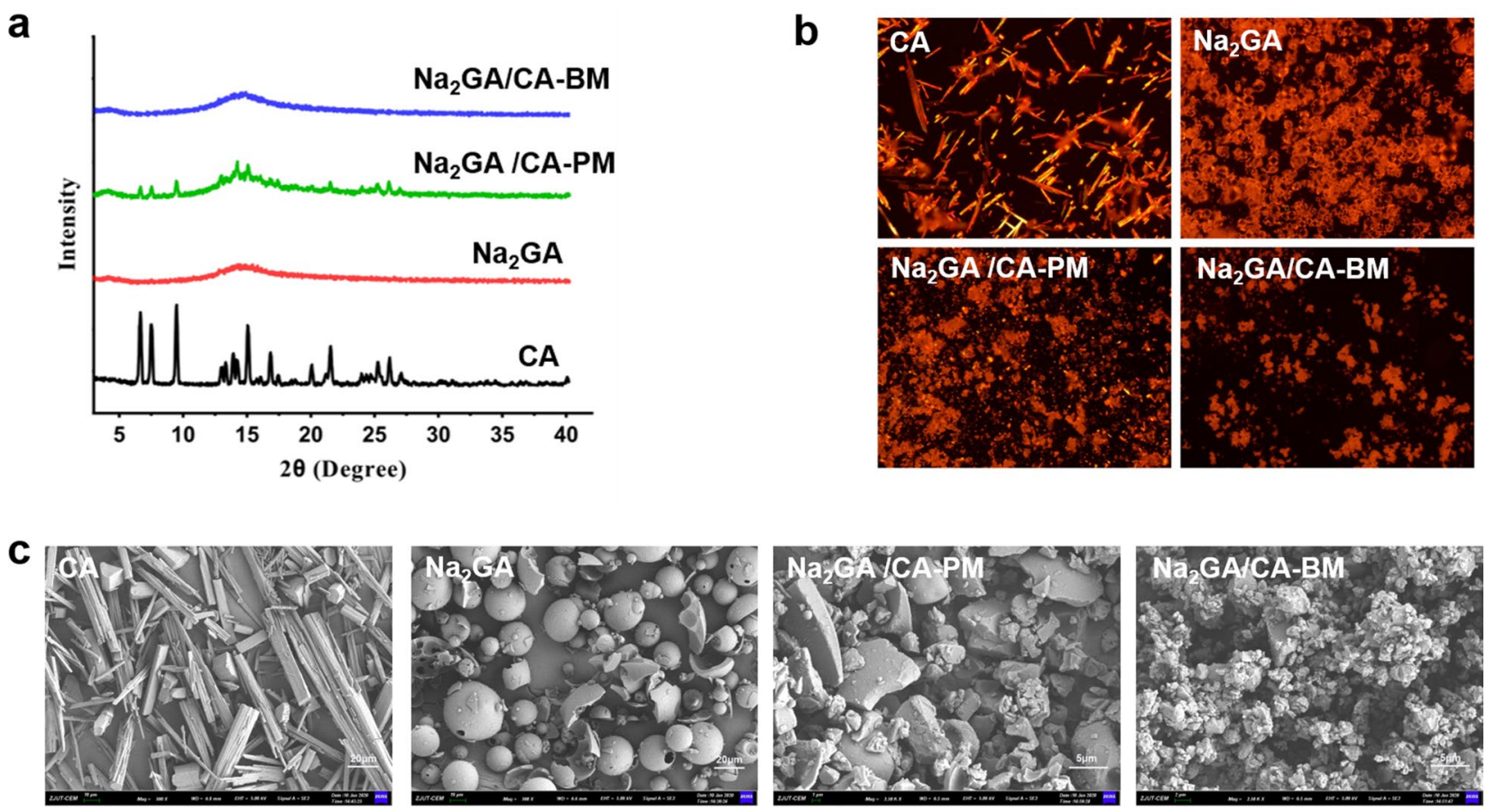

Fig. 2 a X-ray diffraction spectra of $C A, N_{2} G A, N_{2} G A / C A-P M, N a_{2} G A / C A-B M$. b PLM images of $C A$, $N_{2} G A, N_{2} G A / C A-P M, N a_{2} G A / C A-B M$, the magnification was $10 x$. $\mathbf{c}$ The electron micrographs of $C A, N_{2} G A, N_{2} G A / C A-P M, N a_{2} G A / C A-B M$ (The scale bars of $C A, N A_{2} G A$ were $20 \mu m$, the scale bars of $\mathbf{N A}_{\mathbf{2}} \mathbf{G A} / \mathrm{CA}-\mathrm{PM}, \mathbf{N A}_{\mathbf{2}} \mathbf{G A} / \mathrm{CA}-\mathrm{BM}$ were $5 \mu \mathrm{m}$ ) 
The micrographs of CA, $\mathrm{Na}_{2} \mathrm{GA}, \mathrm{Na}_{2} \mathrm{GA} / \mathrm{CA}-\mathrm{PM}$ and $\mathrm{Na}_{2} \mathrm{GA} / \mathrm{CA}-\mathrm{BM}$ obtained from polarized light microscopy are shown in Fig. 2b. As observed in the unprocessed CA, there was extensive birefringence, confirming its crystalline nature. In the $\mathrm{Na}_{2} \mathrm{GA} / \mathrm{CA}-\mathrm{PM}$ micrograph of the physical mixture, the birefringence of CA was dispersed partially. After mechanochemical treatment, $\mathrm{Na}_{2} \mathrm{GA} / \mathrm{CA}-\mathrm{BM}$ was shown no birefringence which identified the amorphous nature of CA embedded in $\mathrm{Na}_{2} \mathrm{GA}$.

Furthermore, the electron micrographs of $\mathrm{CA}, \mathrm{Na}_{2} \mathrm{GA}$, $\mathrm{Na}_{2} \mathrm{GA} / \mathrm{CA}-\mathrm{PM}$ and $\mathrm{Na}_{2} \mathrm{GA} / \mathrm{CA}-\mathrm{BM}$ are shown in Fig. 2c. It could be clearly seen that pure $C A$ was elongated solid and the $\mathrm{Na}_{2} \mathrm{GA}$ was composed of hollow spherical particle with a smooth surface texture. On the contrary, the intact morphology of $\mathrm{CA}$ and $\mathrm{Na}_{2} \mathrm{GA}$ were disappeared and showed a fine and irregularly shaped particle for the ball-milling product $\mathrm{Na}_{2} \mathrm{GA} / \mathrm{CA}-\mathrm{BM}$, suggesting the amorphous solid phase structure of $\mathrm{Na}_{2} \mathrm{GA} /$ CA-BM. The most noteworthy, that the noted particles dispersed more uniformly after being ground for $2.5 \mathrm{~h}$, possibly increased its surface thus improving the velocity of dissolution.

\section{Properties of chrysomycin A micelles in water solution}

When the $\mathrm{Na}_{2} \mathrm{GA} / \mathrm{CA}-\mathrm{BM}$ dissolved in water, $\mathrm{Na}_{2} \mathrm{GA}$ coated CA to form CA micelles. The critical micelle concentration of $\mathrm{Na}_{2} \mathrm{GA} / \mathrm{CA}-\mathrm{BM}$ was about $1.77 \mathrm{mg} / \mathrm{mL}$ (Fig. 3a). The size, zeta potential and surface morphology of micelles are all crucial for interactions between the cell membranes and micelles. As shown in Fig. 3b, the average diameter of the particle was about $131.6 \mathrm{~nm}$ with a narrow size distribution at $25^{\circ} \mathrm{C}$, and its polymer dispersity index (PDI) value was about 0.230 . Moreover, the particle has a negative zeta potential which was $-11.7 \mathrm{mV}$. It was reported that suitable range of particle sizes for evading filtration in reticuloendothelial system (RES) organs was between 100 and $200 \mathrm{~nm}$ [32-35]. In addition, the neutral surface charge of particles (zeta potential $\pm 10 \mathrm{mV}$ ) was proved to prolonged blood circulation and facilitate its accumulation at the tumor tissue [33]. Therefore, $\mathrm{Na}_{2} \mathrm{GA} / \mathrm{CA}-\mathrm{BM}$ formed a great candiate to further use in the animal studies due to proper diameter and potential. The particle size showed relatively stable over a span of $72 \mathrm{~h}$ incubation in cell culture medium with $10 \%$ FBS and a slight increase of size from 116 to $121 \mathrm{~nm}$ during the period. The PDI remained relatively the same at about 0.30 . Furthermore, the images of micelle appearance observed by TEM are depicted in Fig. 3d. The nano-micelle was spherical with smooth boundaries. The diameter of nano-micelle was about $100 \mathrm{~nm}$ and slightly smaller than DLS data because of its shrinkage when dried before TEM detection.

\section{In vitro cytotoxicity and cell uptake}

As shown in Fig. 4a, compared with the suspension of free $\mathrm{CA}, \mathrm{Na}_{2} \mathrm{GA} / \mathrm{CA}-\mathrm{BM}$ have the significant
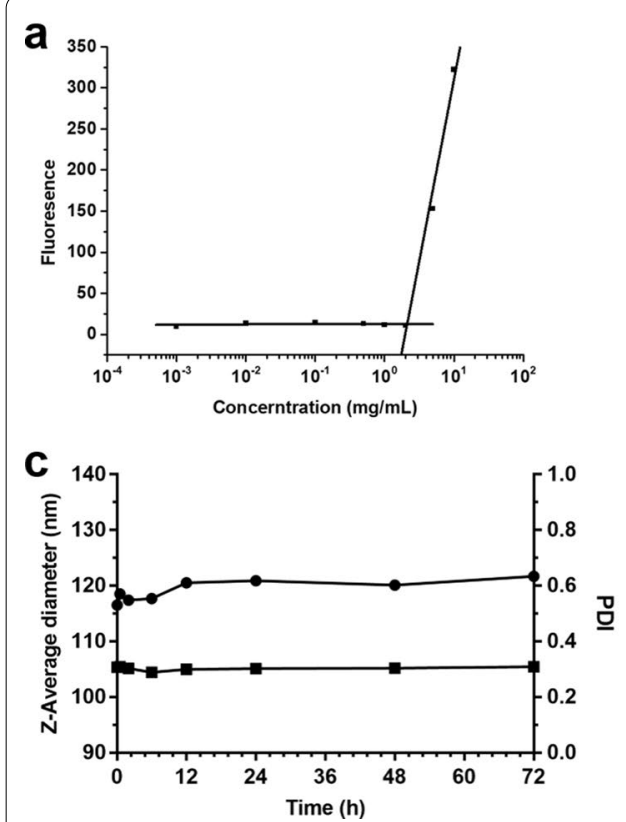
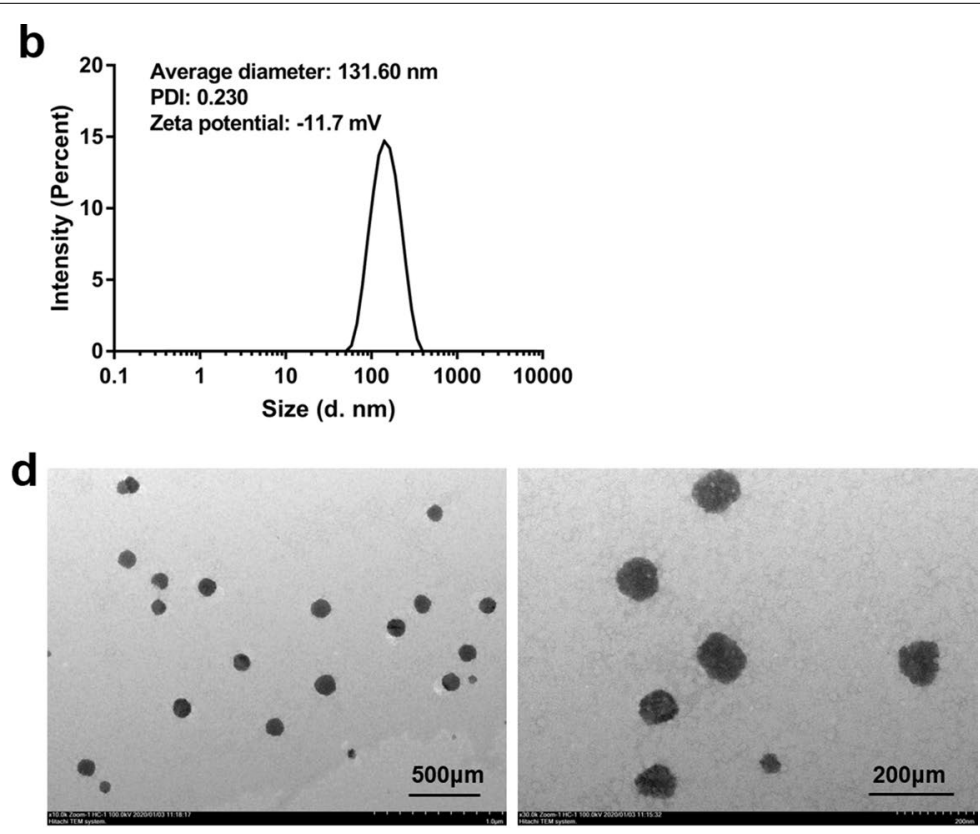

Fig. 3 The CMC, size, zeta potential and surface morphology of $\mathrm{Na}_{2} \mathrm{GA} / C A-B M$. a The CMC value of $\mathrm{Na}_{2} \mathrm{GA} / C A-B M$. b Dynamic light scattering size measurement of $\mathrm{Na}_{2} \mathrm{GA} / \mathrm{CA}$ micelles. $\mathbf{c}$ The stability of $\mathrm{Na}_{2} \mathrm{GA} / \mathrm{CA}-\mathrm{BM}$. $\mathbf{d}$ Transmission electron micrograph (TEM) of $\mathrm{Na}_{2} \mathrm{GA} / \mathrm{CA}$ micelles, the scale bars from left to right were $500 \mu \mathrm{m}, 200 \mu \mathrm{m}$ 


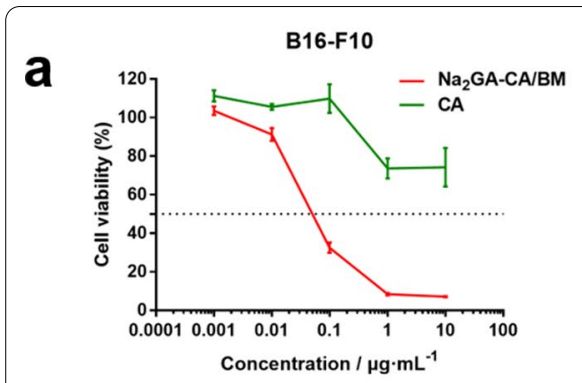

$\mathrm{IC}_{50}: 0.076 \pm 0.013 \mu \mathrm{g} / \mathrm{mL}$

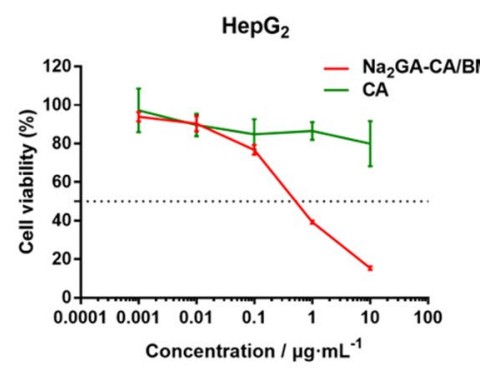

$\mathrm{IC}_{50}: 0.505 \pm 0.010 \mu \mathrm{g} / \mathrm{mL}$

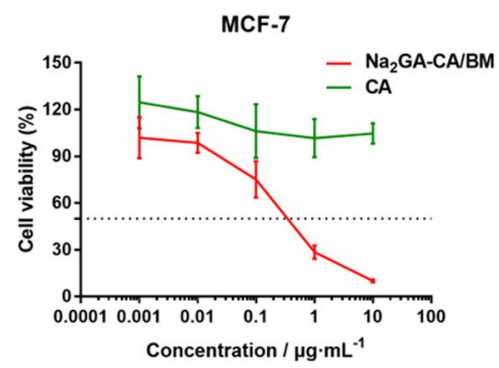

$\mathrm{IC}_{50}: 0.266 \pm 0.056 \mu \mathrm{g} / \mathrm{mL}$

b
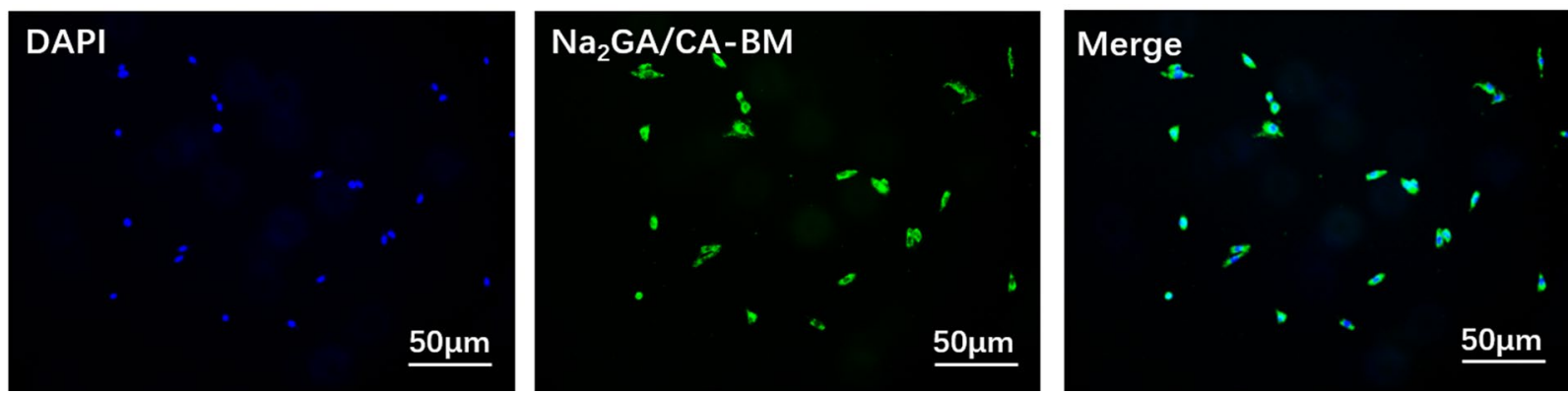

Fig. 4 In vitro cytotoxicity and cellular uptake. a In vitro cytotoxicity of CA and $\mathrm{Na}_{2} \mathrm{GA} / \mathrm{CA}-\mathrm{BM}$ on B16-F10 cells, HepG 2 cells, and MCF-7 cells, respectively $(n=3)$. b Cell uptake of $\mathrm{Na}_{2} \mathrm{GA} / C A-B M / C 6$. Nucleus was stained with DAPI. Images were taken from the DAPI channel (blue), Na ${ }_{2} \mathrm{GA} /$ CA-BM/C6 channel (green), and the overlapped image

Table 2 Cytotoxicity of $\mathrm{Na}_{2} \mathrm{GA}$ in B16-F10, MCF-7 and $\mathrm{HepG}_{2}$ cell lines

\begin{tabular}{lccr}
\hline $\begin{array}{l}\text { Concentration of } \\
\mathbf{N a}_{\mathbf{2}} \mathbf{G A}(\boldsymbol{\mu} \mathbf{g} / \mathbf{m L})\end{array}$ & \multicolumn{2}{l}{ Viability (\%) } \\
\cline { 2 - 4 } & $\mathbf{B 1 6 - F 1 0}$ & MCF-7 & HepG $_{\mathbf{2}}$ \\
\hline 0.099 & $97.1 \pm 9.5$ & $100.9 \pm 7.6$ & $100.9 \pm 5.2$ \\
0.99 & $98.0 \pm 7.7$ & $108.6 \pm 12.7$ & $105.2 \pm 2.9$ \\
9.9 & $92.9 \pm 4.4$ & $104.2 \pm 9.3$ & $102.1 \pm 2.4$ \\
99 & $95.1 \pm 3.6$ & $97.0 \pm 19.2$ & $98.1 \pm 1.5$ \\
990 & $72.0 \pm 6.9$ & $73.1 \pm 4.3$ & $90.6 \pm 5.3$ \\
\hline
\end{tabular}

inhibition ability in all three kinds of tumor cells. The half maximal inhibitory concentrations $\left(\mathrm{IC}_{50}\right)$ of $\mathrm{Na}_{2} \mathrm{GA} / \mathrm{CA}-\mathrm{BM}$ were $0.076 \pm 0.013 \mu \mathrm{g} / \mathrm{mL}$ on B16F10 cells, $0.505 \pm 0.010 \mu \mathrm{g} / \mathrm{mL}$ on $\mathrm{HepG}_{2}$ cells, and $0.266 \pm 0.056 \mu \mathrm{g} / \mathrm{mL}$ on MCF-7 cells, respectively. Especially, the cytotoxicity of $\mathrm{Na}_{2} \mathrm{GA} / \mathrm{CA}-\mathrm{BM}$ on B16F10 cells was statistically significant compared with other two tumor cell lines. As shown in Table 2, the survival rate of all three cell lines was between 72 and $108.6 \%$, which indicated that $\mathrm{Na}_{2} \mathrm{GA}$ itself possessed almost no cytotoxicity in all tested cell lines in the concentration range of $0.099-990 \mu \mathrm{g} / \mathrm{mL}$. Therefore, $\mathrm{Na}_{2} \mathrm{GA} / \mathrm{CA}-\mathrm{BM}$ enhanced the cytotoxic ability of CA, and all obtained cytotoxic action of $\mathrm{Na}_{2} \mathrm{GA} / \mathrm{CA}-\mathrm{BM}$ was due to the CA effect. Mechanical ball milling and $\mathrm{Na}_{2} \mathrm{GA}$ increased the solubility of CA in water, resulting in the increase of its concentration in suspension.

As for the colocalization and internalization by B16F10 cells of coumarin-6-loaded $\mathrm{Na}_{2} \mathrm{GA} / \mathrm{CA}-\mathrm{BM}\left(\mathrm{Na}_{2} \mathrm{GA} /\right.$ $\mathrm{CA}-\mathrm{BM} / \mathrm{C6})$, the fluorescence images were shown in Fig. 4b, indicating that $\mathrm{Na}_{2} \mathrm{GA} / \mathrm{CA}-\mathrm{BM} / \mathrm{C} 6$ was quickly taken up by B16-F10 cells and located in cytoplasm of the tumor cells.

\section{Pharmacokinetic evaluation}

The concentration-time curves of CA in mice plasma are depicted in Fig. 5a, and the pharmacokinetic parameters are summarized in Table 3. From the figure, it could be clearly seen that the bioavailability of $\mathrm{Na}_{2} \mathrm{GA} /$ CA-BM was improved than pure CA. After intragastric administration, $\mathrm{CA}$ and $\mathrm{Na}_{2} \mathrm{GA} / \mathrm{CA}-\mathrm{BM}$ both distributed rapidly and reached the max blood concentration at $0.5 \mathrm{~h}$. What's more, the accumulation time in the body of $\mathrm{Na}_{2} \mathrm{GA} / \mathrm{CA}-\mathrm{BM}$ was longer about twofold than the retention time of free $\mathrm{CA}$. Then, the free $\mathrm{CA}$ was cleared faster from blood than $\mathrm{Na}_{2} \mathrm{GA} / \mathrm{CA}-\mathrm{BM}$, so $\mathrm{Na}_{2} \mathrm{GA} / \mathrm{CA}-\mathrm{BM}$ had a better blood circulation in the body. Compared with $\mathrm{CA}$, the area under the curve of $\mathrm{Na}_{2} \mathrm{GA} / \mathrm{CA}-\mathrm{BM}$ was increased about 1.8 times larger, and the plasma clearance was dramatically decreased. 

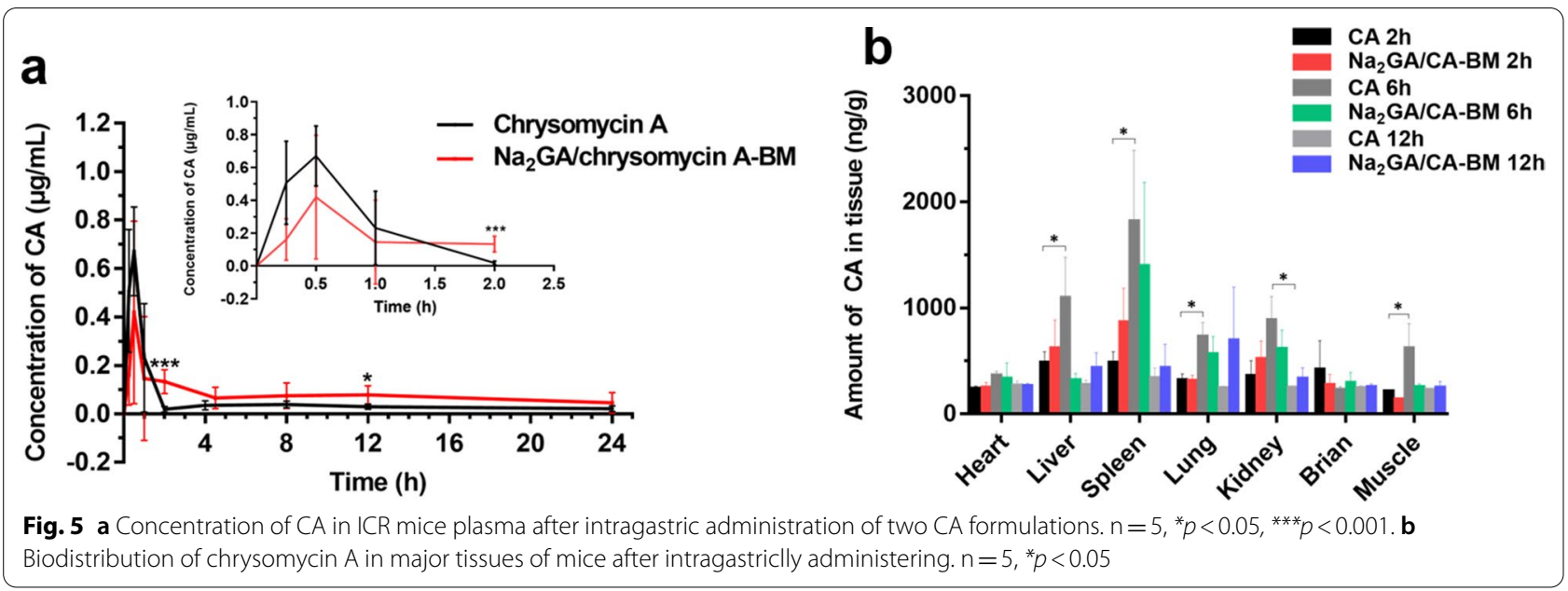

Table 3 The pharmacokinetic parameters of pure chrysomycin $\mathrm{A}$ and $\mathrm{Na}_{2} \mathrm{GA} / \mathrm{CA}-\mathrm{BM}$

\begin{tabular}{|c|c|c|c|c|c|c|}
\hline Samples & $C_{\max }(\mu \mathrm{g} / \mathrm{mL})$ & $T_{\max }(h)$ & $T_{1 / 2}(h)$ & $A U C_{0 \rightarrow t}(\mu \mathrm{g} / \mathrm{mL}, \cdot h)$ & $A \cup C_{0 \rightarrow \infty}(\mu \mathrm{g} / \mathrm{mL}, \cdot \mathrm{h})$ & $\mathrm{CL}(\mathrm{L} / \mathrm{h} / \mathrm{kg})$ \\
\hline$C A$ & 0.67 & 0.50 & 7.55 & 1.62 & 1.72 & 29.02 \\
\hline $\mathrm{Na}_{2} \mathrm{GA} / \mathrm{CA}-\mathrm{BM}$ & 0.42 & 0.50 & 13.98 & 2.17 & 3.09 & 17.14 \\
\hline
\end{tabular}

$C_{\max }$ peak plasm concentration, $T_{\max }$ time to reach peak concentration, $T_{1 / 2}$ half life, $A U C$ area under the plasm concentration-time curve, $C L$ plasm clearance

\section{Tissue distribution study}

Figure $5 \mathrm{~b}$ depicts the distribution concentration of CA in major tissues of mice including heart, liver, spleen, lung, kidney, brain, skeletal muscle after oral dose of $50 \mathrm{mg}$ / $\mathrm{kg}$ of either $\mathrm{Na}_{2} \mathrm{GA} / \mathrm{CA}-\mathrm{BM}$ or CA. After intragastric administration for $2 \mathrm{~h}$, the concentration of $\mathrm{CA}\left(\mathrm{Na}_{2} \mathrm{GA} /\right.$ $\mathrm{CA}-\mathrm{BM}$ group) was high in spleen, and reached to the highest blood concentration at $6 \mathrm{~h}$, after that CA gradually cleared and finally expelled at about $12 \mathrm{~h}$. As for free CA group, CA was distributed mainly in spleen, liver, lung, kidney and muscle, and slowly cleared after $12 \mathrm{~h}$. The main metabolic organ of CA was liver and spleen, while $\mathrm{Na}_{2} \mathrm{GA} / \mathrm{CA}-\mathrm{BM}$ was metabolized mainly in spleen after $6 \mathrm{~h}$. Generally, large size of particles were preferentially absorbed by the liver, and small particles were easily cleared by the spleen, which led to the change in metabolic site of drug $[36,37]$. In comparison, $\mathrm{Na}_{2} \mathrm{GA} /$ CA-BM showed longer blood accumulation in body than free CA after $12 \mathrm{~h}$, which was consistent with the results of the pharmacokinetic study.

\section{In vivo antitumor efficacy}

Due to the better performance on the solubility and bioavailability, we next evaluated the antitumor ability of $\mathrm{Na}_{2} \mathrm{GA} / \mathrm{CA}-\mathrm{BM}$ on B16-F10 tumor-bearing C57BL/6 mice. As shown in Fig. $6 \mathrm{a}, \mathrm{CA}$ and $\mathrm{Na}_{2} \mathrm{GA} / \mathrm{CA}-\mathrm{BM}$ both inhibited the growth of B16-F10 tumors compared with the control group. Meanwhile, $\mathrm{Na}_{2} \mathrm{GA} / \mathrm{CA}-\mathrm{BM}$ showed better tumor suppression ability throughout the treatment, and the tumor inhibition rate was closed $28.76 \%$. From Fig. 6b, it was found that none of the mice loss body weight obviously after treating CA formulations, which indicated no potential systemic toxicities of $\mathrm{CA}$ and $\mathrm{Na}_{2} \mathrm{GA} / \mathrm{CA}-\mathrm{BM}$.

After tumors excision, the weights (Fig. 6c) of tumors treated with $\mathrm{Na}_{2} \mathrm{GA} / \mathrm{CA}-\mathrm{BM}(1.800 \pm 1.246 \mathrm{~g})$ were lower than those of the mice treated with CA $(2.230 \pm 1.429 \mathrm{~g})$ or PBS $(2.212 \pm 1.192 \mathrm{~g})$. In addition, the tumor weights of CA group showed no significant differences compared with the control group.

$H \& E$ staining were shown to observe pathological changes of tumor cells in three groups, As shown in Fig. $6 d$, the tumor cells were dense and had abundant vascular tissue in all three groups. Karyopycnosis and deep staining could be seen, which meant apoptosis and necrosis of cancer cells. Thus, different degrees of apoptosis were seen in tumors treated with CA and $\mathrm{Na}_{2} \mathrm{GA} / \mathrm{CA}-\mathrm{BM}$. In comparison, a large amount of excessive vacuolization and more apoptosis cells were observed in the tissue section of $\mathrm{Na}_{2} \mathrm{GA} / \mathrm{CA}-\mathrm{BM}$ group. Moreover, various size tumor cells could be seen in the envelop layer of tumor tissue treated with PBS and the free $\mathrm{CA}$, rather than in tumor layer of $\mathrm{Na}_{2} \mathrm{GA} / \mathrm{CA}-\mathrm{BM}$ group, indicating the excellent antitumor ability of $\mathrm{Na}_{2} \mathrm{GA} / \mathrm{CA}-\mathrm{BM}$. 

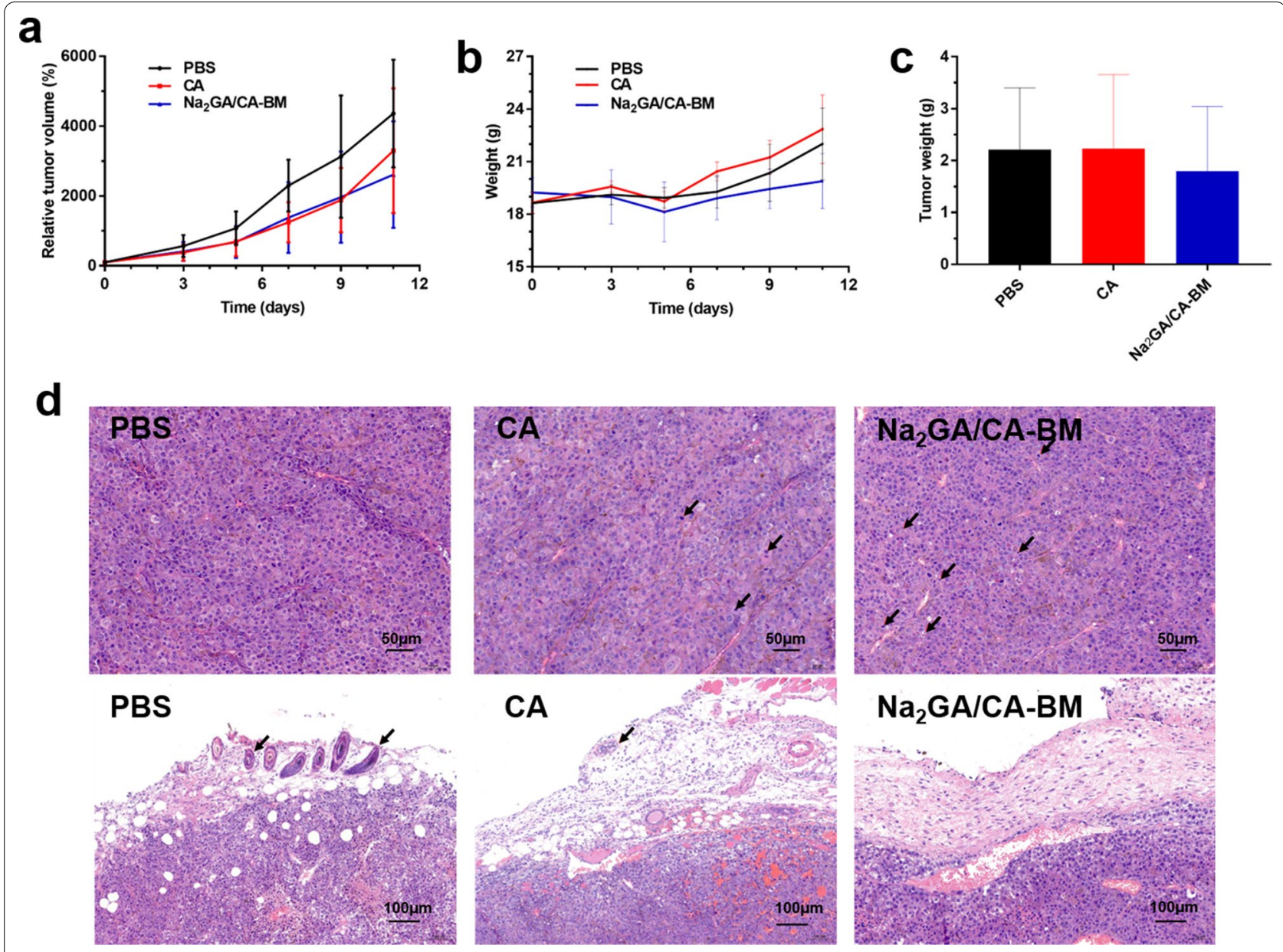

Fig. 6 In vivo antitumor effect test in C57BL/6 mice by intragastric administration $(n=5)$. a The change curve of tumor volume throughout the treatment. b The body weight curve of mice. $\mathbf{c}$ Mean weight of tumor in each group at the end of treatment. $\mathbf{d}$ H\&E staining of tumor tissue sections with envelop layer

\section{Conclusions}

In the present study, an amorphous CA solid dispersion was successfully prepared by mechanical ball milling. As compared to the free $\mathrm{CA}, \mathrm{Na}_{2} \mathrm{GA} / \mathrm{CA}-\mathrm{BM}$ exhibited superior solubility evidenced by a about 50 -fold increase. The physicochemical characteristics analysis showed that CA was dispersed uniformly in the hydrophilic carrier $\left(\mathrm{Na}_{2} \mathrm{GA}\right)$ and transformed from crystals into amorphous state by ball milling. When $\mathrm{Na}_{2} \mathrm{GA} / \mathrm{CA}-\mathrm{BM}$ dissolved in water, $\mathrm{CA}$ encapsulated by $\mathrm{Na}_{2} \mathrm{GA}$ was self-formed to micelles. Consistent with the amorphous nature and self-formed micelles of $\mathrm{Na}_{2} \mathrm{GA} / \mathrm{CA}-\mathrm{BM}$, it showed significant improvement of pharmacokinetic behavior in mice, which increased 1.8 times in oral bioavailability. Moreover, $\mathrm{Na}_{2} \mathrm{GA} /$ CA-BM also exhibited a stronger antitumor ability than CA due to the improvement of oral bioavailability. In summary, our work illustrated an unprecedented and environment-friendly preparation of the CA formulation by ball milling approach, which are promising to enhance the oral bioavailability and antitumor ability of CA, might be considered for efficient anticancer therapy.

\section{Acknowledgements}

This work was supported by Grants from the National Key R\&D Program of China (2018YFC0311005), the National Natural Science Foundation of China (No. 22075247), and the Zhejiang Provincial Natural Science Foundation of China (No. LGF21 C100001), Research Foundation for Advanced Talents of Beijing Technology and Business University (No. 19008020158).

\section{Authors' contributions}

$X S, H Z$ and HW conceived and designed the experiments. FS provided chrysomycin A. ZX, YC, SZ, XG and YH performed experiments. QZ and JX provided technical support for the preparation of $\mathrm{Na}_{2} \mathrm{GA} / \mathrm{CA}-\mathrm{BM}$, DX provided technical support for the antitumor activity. ZX analyzed data and wrote the article. XS interpreted data and reviewed the manuscript. All authors read and approved the final manuscript. 


\section{Availability of data and materials}

The datasets used and/or analysed during the current study are available from the corresponding author on reasonable request.

\section{Declarations}

\section{Ethics approval and consent to participate}

All experimental procedures involving animals performed in this study were previously approved and certified (No. 20200824109) by the animal experiment center of Zhejiang University of Technology, which performed in strict compliance with the PR China legislation for the use and care of laboratory animals.

\section{Consent for publication}

Not applicable.

\section{Competing interests}

The authors declare that they have no competing interests.

\section{Author details}

${ }^{1}$ Collaborative Innovation Center of Yangtze River Delta Region Green Pharmaceuticals and College of Pharmaceutical Science, Zhejiang University of Technology, Hangzhou 310014, China. ${ }^{2}$ School of Light Industry, Beijing Technology and Business University, Beijing 100048, China.

Received: 28 February 2021 Accepted: 25 May 2021

Published online: 31 May 2021

\section{References}

1. Matson JA, Rose WC, Bush JA, Myllymaki R, Bradner WT, Doyle TW. Antitumor activity of chrysomycins M and V. J Antibiot. 1989;42:1446-8.

2. Weiss U, Yoshihira K, Highet RJ, White RJ, Wei TT. The chemistry of the antibiotics chrysomycin A and B Antitumor activity of chrysomycin A.J Antibiot. 1982;35:1194-201.

3. Li Y, Huang X, Ishida K, Maier A, Kelter G, Jiang Y, Peschel G, Menzel K, Li M, Wen M, Xu L, Grabley S, Fiebig H, Jiang C, Hertweck C, Sattler I. Plasticity in gilvocarcin-type C-glycoside pathways: discovery and antitumoral evaluation of polycarcin $\vee$ from Streptomyces polyformus. Org Biomol Chem. 2008;6:3601-5

4. Wada S, Sawa R, Iwanami F, Nagayoshi M, Kubota Y, lijima K, Hayashi C, Shibuya Y, Hatano M, Igarashi M, Kawada M. Structures and biological activities of novel 4 '-acetylated analogs of chrysomycins A and B. J Antibiot. 2017;70:1150.

5. Kudinova MK, Kuliaeva V, Potapova NP, Rubasheva LM, Maksimova TS. Separation and characteristics of the components of the antibiotic virenomycin. Antibiotiki. 1982;27:507-11.

6. Muralikrishnan B, Dan VM, Vinodh JS, Jamsheena V, Ramachandran R, Thomas S, Dastager SG, Kumar KS, Lankalapalli RS, Kumar RA. Antimicrobial activity of chrysomycin a produced by Streptomyces sp. against Mycobacterium tuberculosis. Rsc Adv. 2017;7:36335-9.

7. Jain SK, Pathania AS, Parshad R, Raina C, Ali A, Gupta AP, Kushwaha M, Aravinda S, Bhushan S, Bharate SB, Vishwakarma RA. Chrysomycins A-C, antileukemic naphthocoumarins from Streptomyces sporoverrucosus. Rsc Adv. 2013;3:21046-53.

8. Lorico A, Long BH. Biochemical characterisation of elsamicin and other coumarin-related antitumour agents as potent inhibitors of human topoisomerase II. Eur J Cancer. 1993;29A:1985-91.

9. Gu Q, Xing JZ, Huang M, He C, Chen J. SN-38 loaded polymeric micelles to enhance cancer therapy. Nanotechnology. 2012. https://doi.org/10. 1088/0957-4484/23/20/205101.

10. Liu Y, Yang G, Baby T, Tengjisi, Chen D, Weitz DA, Zhao C. Stable polymer nanoparticles with exceptionally high drug loading by sequential nanoprecipitation. Angew Chem Int Edit. 2020;59:4720-8.

11. Hammoud Z, Khreich N, Auezova L, Fourmentin S, Elaissari A, GreigeGerges H. Cyclodextrin-membrane interaction in drug delivery and membrane structure maintenance. Int J Pharmaceut. 2019;564:59-76.

12. Terauchi M, Inada T, Tonegawa A, Tamura A, Yamaguchi S, Harada K, Yui N. Supramolecular inclusion complexation of simvastatin with methylated beta-cyclodextrins for promoting osteogenic differentiation. Int J Biol Macromol. 2016;93:1492-8.

13. Javeer SD, Patole R, Amin P. Enhanced solubility and dissolution of simvastatin by HPMC-based solid dispersions prepared by hot melt extrusion and spray-drying method. J Pharm Investig. 2013;43:471-80.

14. Wang F, Xiao X, Yuan Y, Liu J, Liu Y, Yi X. Solubilization of phloretin via steviol glycoside-based solid dispersion and micelles. Food Chem. 2020. https://doi.org/10.1016/j.foodchem.2019.125569.

15. Saggar S, Upadhayay A, Goswami M. Formulation and evaluation of solid self-emulsifying drug delivery system of bambuterol hydrochloride. Indian J Pharm Sci. 2019;81:661-72.

16. Zhang Q, Polyakov NE, Chistyachenko YS, Khvostov MV, Frolova TS, Tolstikova TG, Dushkin AV, Su W. Preparation of curcumin self-micelle solid dispersion with enhanced bioavailability and cytotoxic activity by mechanochemistry. Drug Deliv. 2018;25:198-209.

17. Bahri M, Kazemian H, Rohani S, Haghighat F. Mechanochemical synthesis of CPM-5: a green method. Chem Eng Technol. 2017;40:88-93.

18. Wei G, Li Y, Zhang L, Cai S, Zhu T, Li Z, Mo J. Synthesis of bentonite-supported Fe(II) and heteropolyacid (HPW) composite through a mechanochemical processing. Appl Clay Sci. 2018;152:342-51.

19. Da Silva CCP, de Melo CC, Souza MS, Diniz LF, Carneiro RL, Ellena J. 5-Fluorocytosine/5-fluorouracil drug-drug cocrystal: a new development route based on mechanochemical synthesis. J Pharm Innov. 2019;14:50-6.

20. Douroumis D, Ross SA, Nokhodchi A. Advanced methodologies for cocrystal synthesis. Adv Drug Deliver Rev. 2017;117:178-95.

21. Xu W, Wen M, Yu J, Zhang Q, Polyakov NE, Dushkin AV, Su W. Mechanochemical preparation of kaempferol intermolecular complexes for enhancing the solubility and bioavailability. Drug Dev Ind Pharm. 2018;44:1924-32.

22. Sun X, Zhu D, Cai Y, Shi G, Gao M, Zheng M. One-step mechanochemical preparation and prominent antitumor activity of $\mathrm{SN}-38$ self-micelle solid dispersion. Int J Nanomed. 2019;14:2115-26.

23. Boldyrev WV. Mechanochemical modification and synthesis of drugs. J Mater Sci. 2004;39:5117-20.

24. Descamps M, Willart JF. Perspectives on the amorphisation/milling relationship in pharmaceutical materials. Adv Drug Deliver Rev. 2016;100:51-66.

25. Pompei R, Laconi S, Ingianni A. Antiviral properties of glycyrrhizic acid and its semisynthetic derivatives. Mini-Rev Med Chem. 2009;9:996-1001.

26. Bernela M, Ahuja M, Thakur R. Enhancement of anti-inflammatory activity of glycyrrhizic acid by encapsulation in chitosan-katira gum nanoparticles. Eur J Pharm Biopharm. 2016;105:141-7.

27. Su X, Wu L, Hu M, Dong W, Xu M, Zhang P. Glycyrrhizic acid: a promising carrier material for anticancer therapy. Biomed Pharmacother. 2017:95:670-8.

28. Yang F, Zhang Q, Liang Q, Wang S, Zhao B, Wang Y, Cai Y, Li G. Bioavailability enhancement of paclitaxel via a novel oral drug delivery system: paclitaxel-loaded glycyrrhizic acid micelles. Molecules. 2015;20:4337-56.

29. Kong R, Zhu X, Meteleva ES, Chistyachenko YS, Suntsova LP, Polyakov NE, Khvostov MV, Baev DS, Tolstikova TG, Yu J, Dushkin AV, Su W. Enhanced solubility and bioavailability of simvastatin by mechanochemically obtained complexes. Int J Pharmaceut. 2017:534:108-18.

30. Selyutina OY, Polyakov NE, Korneev DV, Zaitsev BN. Influence of glycyrrhizin on permeability and elasticity of cell membrane: Perspectives for drugs delivery. Drug Deliv. 2016;23:858-65.

31. Du L, Dushkin AV, Chistyachenko YS, Polyakov NE, Su W. Investigation the inclusion complexes of valsartan with polysaccharide arabinogalactan from larch Larix sibirica and (2-hydroxypropyl)-beta-cyclodextrin: preparation, characterization and physicochemical properties. J Incl Phenom Macro. 2016:85:93-104.

32. Chen M, Li W, Zhang X, Dong Y, Hua Y, Zhang H, Gao J, Zhao L, Li Y, Zheng A. In vitro and in vivo evaluation of $\mathrm{SN}-38$ nanocrystals with different particle sizes. Int J Nanomedicine. 2017;12:5487-500.

33. Li S, Huang L. Pharmacokinetics and biodistribution of nanoparticles. Mol Pharmaceut. 2008;5:496-504

34. Sun Q, Zhou Z, Qiu N, Shen Y. Rational design of cancer nanomedicine: nanoproperty integration and synchronization. Adv Mater. 2017. https:// doi.org/10.1002/adma.201606628. 
35. Liu D, Mori A, Huang L. Role of liposome size and RES blockade in controlling biodistribution and tumor uptake of GM1-containing liposomes. Biochim Biophys Acta. 1992;1104:95-101.

36. Li M, Al-Jamal KT, Kostarelos K, Reineke J. Physiologically based pharmacokinetic modeling of nanoparticles. ACS Nano. 2010;4:6303-17.

37. Hoshyar N, Gray S, Han H, Bao G. The effect of nanoparticle size on in vivo pharmacokinetics and cellular interaction. Nanomedicine. 2016;11:673-92.

\section{Publisher's Note}

Springer Nature remains neutral with regard to jurisdictional claims in published maps and institutional affiliations.
Ready to submit your research? Choose BMC and benefit from:

- fast, convenient online submission

- thorough peer review by experienced researchers in your field

- rapid publication on acceptance

- support for research data, including large and complex data types

- gold Open Access which fosters wider collaboration and increased citations

- maximum visibility for your research: over $100 \mathrm{M}$ website views per year

At BMC, research is always in progress.

Learn more biomedcentral.com/submissions 